\title{
LEVELS OF INFECTION AND COLONIZATION OF SOME ORAL BACTERIA AFTER USE OF NAF, CHLORHEXIDINE AND A COMBINED CHLORHEXIDINE WITH NAF MOUTHRINSES
}

\author{
Kenio Costa Lima ${ }^{1,2}$; Aline A. Neves ${ }^{3}$; Janine B. Beyruth ${ }^{1}$; Fernando A.C. Magalhães ${ }^{1}$; Milton de Uzeda ${ }^{1 *}$ \\ ${ }^{1}$ Instituto de Microbiologia "Prof. Paulo de Góes", Universidade Federal do Rio de Janeiro, Rio de Janeiro, RJ, Brasil. \\ ${ }^{2}$ Departamento de Odontologia, Universidade Federal do Rio Grande do Norte, Natal, RN, Brasil. \\ ${ }^{3}$ Faculdade de Odontologia, Universidade Federal do Rio de Janeiro, Rio de Janeiro, RJ, Brasil
}

Submitted: November 28, 2000; Returned to authors for corrections: April 03, 2001; Approved: June 21, 2001

SHORT COMMUNICATION

\begin{abstract}
This study was carried out to evaluate levels of infection of bacteria involved in caries and oral streptococci and their colonization after use of mouthrinses with $\mathrm{NaF}$, chlorhexidine and chlorhexidine plus $\mathrm{NaF}$. Combination of chlorhexidine and fluoride was the only agent that reduced levels of Streptococcus mutans (group) for 30 days.
\end{abstract}

Key words: chlorhexidine, sodium fluoride, cariogenic bacteria, oral streptococci

Mechanical methods are known for prevention and control of oral diseases. Some authors consider that they consume time for both professional and patients (14). It is important to consider yet that they are laborious and difficult for many patients $(14,24)$ and impossible to others (24). Based upon these considerations and aiming to make dental plaque control more accessible to a significant proportion of population less laborious methods are wished (32). Among these methods are the chemical controls that have fascinated men for over 400 years (7). Chlorhexidine was originally introduced as commercial products in 1957 in Europe as an antiseptic cream for skin wounds (18). It has generated an increasing interest among dental community since its introduction as a $0.2 \%$ mouthrinse in experimental gingivitis study in 1970 (16). Apparently by acting via a generalized perturbation of the bacterial membrane rather than the antibiotic method, there is much less opportunity for bacterial resistance development, which was an early concern with it (18). Concerning fluoride, the first mouthrinse recommended in the United States was in the fourties for schoolchildren as caries prevention. Nowadays, FDA authorized the sale under control with mouthrinses of $0.05 \%$ sodium fluoride (NaF) (10). In spite of several antibacterial mechanisms suggested for the action of fluoride, it seems that the effect over plaque activity is low, reducing only its metabolic activity $(2,9)$ but not reducing bacterial concentration (17). Therefore, the purpose of this study was to evaluate levels of infection of major bacteria involved in caries process and the major group of bacteria isolated in the mouth, the streptococci, and their colonization after use of mouthrinses with $\mathrm{NaF}$, chlorhexidine and chlorexidine plus $\mathrm{NaF}$.

The subject population was selected from a group of military cadets from 18 through 25 years of age by means of previous screening based on levels of infection of mutans streptococci ( $>250.000 \mathrm{CFU} / \mathrm{ml}$ saliva) and therefore submitted to a high microbiological risk of caries (30). All the 60 selected patients signed an agreement term where they became aware of aims, risks and benefits of the study, allowing their inclusion. The subject population was divided into three groups according to products that they would use. This study was a double-blind where each group had 20 subjects. Subjects rinsed twice a day during 15 days with $10 \mathrm{ml}$ of only one of the following solutions: a) $\mathrm{NaF}$ $(0.05 \%$, aqueous commercial solution prepared by Herpo, Rio de Janeiro, RJ) b) $0.12 \%$ of chlorhexidine digluconate (Periogard®,Colgate-Palmolive, Osasco, SP), c) $0.05 \%$ of NaF plus $0.12 \%$ of chlorhexidine digluconate (Duplak $®$, Herpo Ltda, Rio de Janeiro, RJ) according to recommendations for patients with

\footnotetext{
* Corresponding author. Mailing address: Laboratório de Microbiologia Oral, Instituto de Microbiologia "Prof. Paulo de Góes" - UFRJ, Caixa Postal 68040. Cidade Universitária, 21941-590, Rio de Janeiro, RJ, Brasil. Tel.: (+5521) 260-4139. Fax: (+5521) 560-8344. E-mail: immmmuz@microbio.ufrj.br
} 
high risk of caries (15). Thirty minutes after toothbrushing, the individuals rinsed with solutions containing chlorhexidine to avoid interference of sodium lauryl sulfate from dentifrices (1). When the period of 15 days was over, the patients remained under observation for a month for disclosing concentration of bacterial population studied. To verify levels of infection and colonization by mutans streptococci, lactobacilli and total oral streptococci, saliva stimulated with gum base was collected from all patients in three periods: a) before treatment with each product (baseline), b) immediately after finishing treatment $\left.\left(\mathrm{T}_{0}\right), \mathrm{c}\right) 15$ days after $\left.\left(\mathrm{T}_{15}\right), \mathrm{d}\right)$ 30 days after $\left(\mathrm{T}_{30}\right)$. Saliva was collected and transported in a cooler, and was immediately processed. Concerning total oral streptococci, diluted saliva was inoculated on Mitis-Salivarius Agar (Difco Laboratories, Detroit, Michigan) (3). For cultivation of mutans streptococci diluted saliva was inoculated on MitisSalivarius Agar added with $15 \%$ of sucrose, $0.1 \%$ potassium tellurite solution and bacitracin $(0.2 \mathrm{IU} / \mathrm{ml})(6)$. These plates were incubated in anaerobic atmosphere for $48 \mathrm{~h}$ and after this period colonies were counted. Concerning oral lactobacilli, diluted saliva was inoculated with pour-plate technique on Rogosa-SL Agar (Difco Laboratories, Detroit, Michigan) (25) and incubated in aerobic atmosphere at $37^{\circ} \mathrm{C}$ for $72 \mathrm{~h}$. The same procedure used for other bacteria was employed for counting these microorganisms. Data obtained were statistically analyzed for differences within and among groups and periods of experiment into each groups by means of the ANOVA and Tukey's tests. The significance level was established at $5 \%(\mathrm{p}<0.05)$.

Considering all subject groups in relation to oral streptococci, in Table 1 is observed that there was no significant difference among them $(\mathrm{p}<0.05)$ nor among period of experiment within each group $(\mathrm{p}<0.05)$. According Table 1 , subjects that mouthrinsed with $\mathrm{NaF}$ (group 1) showed no reduction of their levels of infection by mutans streptococci alongside the study with no significant difference among periods of experiment $(\mathrm{p}<0.05)$. However, concerning those subjects who mouthrinsed chlorhexidine combined with $\mathrm{NaF}$ (group 2), there was a significant difference among experimental period $(\mathrm{p}>0.05)$. This difference was observed among values of baseline and at different times $\left(\mathrm{T}_{0}, \mathrm{~T}_{15}\right.$ and $\mathrm{T}_{30}$ ) . Concerning individuals from group 3 , who mouthrinsed with chorhexidine, levels of infection by mutans streptococci were significantly reduced $(\mathrm{p}>0.05)$ between baseline and $\mathrm{T}_{0}$. Comparing to other periods with baseline we can observe that there is no significant difference ( $\mathrm{p}<0.05)$. Comparing levels of infection by mutans streptococci with periods among groups no significant difference was observed $(\mathrm{p}<0.05)$. This shows that the reduction observed in group $2\left(\mathrm{~T}_{0}, \mathrm{~T}_{15}\right.$ and $\left.\mathrm{T}_{30}\right)$ and, that observed in group $3\left(\mathrm{~T}_{0}\right)$ was not sufficient to reduce levels below those observed in group 1 at the same period. Considering all groups, in Table 1 is observed with relation to lactobacilli there was not a significant difference among them $(\mathrm{p}<0.05)$ nor among periods for each group $(\mathrm{p}<0.05)$.

Recently, the association of chlorhexidine and fluoride was proposed. Thus, this study was carried out to evaluate levels of infection and colonization of the major cariogenic bacteria and oral streptococci after use of fluoride, chlorhexidine and fluoride plus chlorhexidine mouthrinses. After two weeks of mouthrinses of fluoride no reduction was observed on the levels of infection by oral streptococci, mutans streptococci and oral lactobacilli nor any difference among baseline, at $\mathrm{T}_{0}$, $\mathrm{T}_{15}$ and $\mathrm{T}_{30}$ of this treatment group regarding the other groups. Concerning fluoride it was reported that minimal inhibitory concentration to viridans streptococci was $0.125 \%$ (23), therefore a concentration higher than our study $(0.05 \%)$. Major properties of fluoride in plaque control and as an antimicrobial product are the abilities to change the enamel surface energy (28) and inhibit the glycolysis and transport of nutrients based on phosphoenolpyruvate $(8,17)$ and in a system based on ATPase linked to cell membrane by $\mathrm{pH}$ gradient (9). Some oral lactobacilli are ten times more resistant to fluoride than streptococci $(8,17,22)$. In our study the reduction of lactobacilli was not observed due to low concentration used in daily mouthrinses. Combination of fluoride and chlorhexidine was effective to reduce levels of mutans streptococci (around 1 log.) and to keep it reduced for 30 days. However no reduction was observed with oral streptococci and lactobacilli. Our results are in accordance with most the authors where is observed a broad effect of this association to reduce mutans streptococci $(12,20,29,30)$. This effect is formerly derived from bactericidal

Table 1. Means \pm standard-deviations (in LOG) of number of CFUs of oral streptococci, Streptococcus mutans ( group ) and lactobacilli / $\mathrm{ml}$ of saliva in several periods (in days) and groups of patients treated with $\mathrm{NaF}, \mathrm{NaF}+$ Chlorhexidine (CHX) and CHX.

\begin{tabular}{cccccccccc}
\hline & \multicolumn{3}{c}{ Oral streptococci } & \multicolumn{3}{c}{ Streptococcus mutans (group) } & \multicolumn{3}{c}{ Lactobacilli } \\
\hline Periods & $\mathrm{NaF}$ & $\mathrm{NaF}+\mathrm{CHX}$ & $\mathrm{CHX}$ & $\mathrm{NaF}$ & $\mathrm{NaF}+\mathrm{CHX}$ & $\mathrm{CHX}$ & $\mathrm{NaF}$ & $\mathrm{NaF}+\mathrm{CHX}$ & $\mathrm{CHX}$ \\
\hline Baseline & $7.87 \pm 0.66$ & $7.86 \pm 0.71$ & $7.85 \pm 0.50$ & $5.86 \pm 0.69$ & $6.10 \pm 0.65$ & $5.86 \pm 0,68$ & $3.82 \pm 1.10$ & $4.36 \pm 1,91$ & $4.78 \pm 1.54$ \\
$\mathrm{~T}_{0}$ & $7.95 \pm 0.45$ & $7.63 \pm 0.66$ & $8.06 \pm 0.62$ & $5.60 \pm 0.70$ & $5.30 \pm 0.72 *$ & $5.20 \pm 0,55^{*}$ & $4.11 \pm 1.38$ & $3.88 \pm 1,96$ & $4.00 \pm 1.57$ \\
$\mathrm{~T}_{15}$ & $7.83 \pm 0.52$ & $7.78 \pm 0.64$ & $8.01 \pm 0.48$ & $5.43 \pm 0.74$ & $5.48 \pm 0.66^{*}$ & $5.36 \pm 0,99$ & $4.26 \pm 1.36$ & $4.06 \pm 1,69$ & $4.23 \pm 1.34$ \\
$\mathrm{~T}_{30}$ & $7.97 \pm 0.43$ & $7.94 \pm 0.55$ & $7.99 \pm 0.59$ & $5.58 \pm 0.72$ & $5.45 \pm 0.90^{*}$ & $5.34 \pm 0,80$ & $4.10 \pm 1.77$ & $3.56 \pm 1,99$ & $3.85 \pm 1.59$ \\
\hline
\end{tabular}

* values different significantly $(\mathrm{p}>0,05)$; baseline $=$ before treatment; $\mathrm{T} 0=$ immediately after treatment; $\mathrm{T} 15=15$ days after treatment; $\mathrm{T} 30=30$ days after treatment. 
action of chlorhexidine $(19,20)$ followed its bacteriostatic action that in association with fluoride would inhibit bacterial metabolism in different sites. Bacterial recolonization is observed after some days $(26,29)$ or months based on adopted treatment, infection levels, sucrose ingestion or dental restorations. In this study the recolonization of mutans streptococci did not occur 30 days after treatment, probably due to combined action of both products and because infection level at baseline was high. Despite reduction of mutans streptococci levels, oral streptococci were not total, suggesting that the site and function of mutans streptococci in oral ecosystem may be occupied by other bacteria, probably some strain of streptococci not reduced by this treatment. This hypothesis is supported by the fact that some oral streptococci strains show variable susceptibility to chlorhexidine and fluoride $(17,19,21)$. Concerning oral lactobacilli, levels were not reduced by fluoride and chlorhexidine probably because these microorganisms were hidden in habitats not affected by these products as observed among irradiated patients (12). Daily mouthrinses with chlorhexidine alone reduced levels of infection by mutans streptococci immediately after treatment $\left(\mathrm{T}_{0}\right)$, afterwards they returned to baseline levels. Despite of some other studies had observed that this reduction had been more prolonged $(4,5,11)$, in our study this fact was not observed probably due to low concentration used. Toxic effects of chlorhexidine on mutans streptococci is due to affect the hydrofobicity (13). Oral streptococci and lactobacilli were not affected by treatment with chlorhexidine mouthrinses. Oral streptococci shows varied susceptibilities to chlorhexidine $(19,21)$ from 4 to $32 \mu \mathrm{g} / \mathrm{ml}(27)$. Oral lactobacilli frequently are not affected by chlorhexidine because of difficulty to achieve niches of lactobacilli into mouth $(4,17)$. Regardless of reduction promoted by the use of chlorhexidine with fluoride for 30 days after mouthrinses and chlorhexidine immediately after treatment, these reductions must be questioned. Indeed infection levels observed after those rinses did not reduce as significantly as in fluoride group. In addition those solutions probably causes shifts in oral microbial ecosystem, thus, we can suggest that these compounds can not be used without prescriptions and should be specifically indicated for some patients. On the other hand, we observed that the combination of chlorhexidine and fluoride solution is able to reduce mutans streptococci by 30 days. Finally, we concluded that the use of this solution, if not well controlled, could be selective for other streptococci in oral environment.

\section{ACKNOWLEDGMENTS}

The authors are most grateful to the staff of Centro de Estudos de Pessoal (Brazilian Army, Rio de Janeiro, RJ, Brazil) where part of the research was carried out. It was supported by grants and scholarships from the following Brazilian agencies: CNPq, PRONEX-MCT, CAPES, FAPERJ and FINEP.

\section{RESUMO}

\section{Níveis de infecção e colonização de algumas bactérias orais após o uso de soluções de fluoreto de sódio, clorexidina e de uma combinação de fluoreto de sódio e clorexidina}

O objetivo deste estudo foi avaliar os níveis de infecção de bactérias cariogênicas e estreptococos orais e sua colonização após uso de bochechos com $\mathrm{NaF}$, clorexidina e clorexidina e $\mathrm{NaF}$ associados. Associação de clorexidina e $\mathrm{NaF}$ foi o único agente que reduziu os níveis de Streptococcus mutans (grupo) por 30 dias.

Palavras-chave: clorexidina, fluoreto de sódio, bactérias cariogênicas, estreptococos orais.

\section{REFERENCES}

1. Barkvoll, P.; Rölla G.; Svendsen A.K. Chlorhexidine interactions with sodium lauryl sulfate in vivo. J. Dent. Res., 68:1722-1723, 1989

2. Bowden, G.H.W. Effects of fluoride on the microbial ecology of dental plaque. J. Dent. Res., 69:653-659, 1990.

3. Chapman, J.T. A selective medium for oral and fecal streptococci. Am. J. Digest. Dis., 13:105, 1946.

4. Emilson, C.G. Potential efficacy of chlorhexidine against mutans streptococci and human dental caries. J.Dent. Res., 73:682-691, 1994.

5. Emilson, C.G.; Lindquist B.; Wennerholm, K. Recolonization of human tooth surfaces by Streptococcus mutans after supression by chlorhexidine treatment. J. Dent. Res., 66:1503-1508, 1987.

6. Gold,O.G; Jordan, H.V.; van Houte, J. A selective medium for Streptococcus mutans. Archs. Oral Biol., 18:1357-1364, 1973.

7. Guggenheim B.; Schmid, R. Chemical plaque control: what in vitro and animal test systems are appropriate? J. Dent. Res., 68:1645-1654, 1989.

8. Hamilton, I.; Bowden G. Effect of fluoride on oral microorganisms. In: Hamilton, I.R. (ed). Fluoride in dentistry. Munksgaard, Copenhagen, 1988, p.77-103.

9. Hamilton I.R. Biochemical effects of fluoride on oral bacteria. $J$. Dent. Res., 69:660-667, 1990.

10. Harris, N.O. Dentifrices, mouthrinses, and oral irrigators. In: Harris, O.; Christen, A. (eds.). Primary preventive dentistry. 3rd ed. Appleton \& Lange, East Norwalk, 1991, p.141-152.

11. Hildebrandt G.H.; Pape Jr., H.R.; Syed S.A.; Gregory, W.A.; Friedman, M. Effect of slow-release chlorhexidine mouthguards on the levels of selected salivary bacteria. Caries Res., 26: 268-274, 1992.

12. Joyston-Bechal, S.; Hayes, K.; Davenport, E.S.; Hardie, J.M. Caries incidence, mutans streptococci and lactobacilli in irradiated patients during a 12 -month preventive program using chlorhexidine and fluoride. Caries Res., 26:384-390, 1992.

13. Koontongkaew, S.; Jitpukdeebodintra, S. Amphiphilic property of chlorhexidine and its toxicity against Streptococcus mutans GS-5. J. Nihon Univ. Sch. Dent., 36:235-240, 1994.

14. Lang, N. Antissépticos e antibióticos em periodontia. In: Lindhe, J.(ed) Tratado de Periodontologia Clínica. 2.ed. Guanabara Koogan, Rio de Janeiro,1992, p.270-284.

15. Lang, N.P.; Brecx, M.C. Chlorhexidine digluconate- an agent for chemical plaque control and prevention of gingival inflammation. J. Periodont. Res., suppl.: 74-89, 1986.

16. Löe, H.; Schiott, C.R. The effect of mouthrinse and topical applications of chlorhexidine on the development of dental plaque and gingivitis in man. J. Periodont. Res., 6: 79-83, 1970. 
17. Maltz, M.; Emilson, C.G. Susceptibility of oral bacteria to various fluoride salts. J. Dent. Res., 61:786-790, 1982.

18. Mandel, I. The mouthrinse wars. J. Clin. Periodontol., 60:478-480, 1989.

19. McDermid, A.S.; McKee, A.S.; Marsh, P.D. A mixed-culture chemostat system to predict the effect of anti-microbial agents on the oral flora: preliminary studies using chlorhexidine. J. Dent. Res., 66:1315-1320, 1987.

20. Meurman, J.H. Ultrastructure, growth, and adherence of Streptococcus mutans after treatment with chlorhexidine and fluoride. Caries Res., 22:283-287, 1988.

21. Mikkelsen, L.; Jensen, S.B.; Schiott, C.R.; Löe, H. Classification and prevalence of plaque streptococci after two years oral use of chlorhexidine. J. Periodont. Res., 16:646-658, 1981.

22. Milnes, A.R.; Bowden, G.H.; Hamilton, I.R. Effect of $\mathrm{NaF}$ and $\mathrm{pH}$ on the growth and glycolytic rate of recently isolated strains of oral Lactobacillus species. J. Dent. Res., 64: 401-404, 1985.

23. Miranda, V.C.; Piszolito, A.C. Ação do flúor sobre os estreptococos orais- concentração inibitória mínima. Rev. Assoc. Paul. Cirurg. Dent., 34:480-485, 1980.

24. Page, R.C. Review of the guidelines for acceptance of chemotherapeutic products for the control of supragingival dental plaque and gingivitis. J. Dent. Res., 68:1640-1644, 1989.
25. Rogosa, M.; Mitchell, J.A.; Wiseman, R.F. A selective medium for the isolation and enumeration of oral lactobacilli. J. Dent. Res., 30:682689, 1951

26. Schaeken, M.J.M.; de Jong, M.H.; Franken, H.C.M.; van der Hoeven, J.S. Effects of highly concentrated stannous fluoride and chlorhexidine regimens on human dental plaque flora. J. Dent. Res., 65:57-61, 1986.

27. Schiott, C.R.; Löe, H. The sensitivity of oral streptococci to chlorhexidine. J. Periodont. Res., 7:192-194, 1972.

28. Sönju, T. Película - formação, composição e possível função. In: Thylstrup, A.; Fejerskov, O.

29. (eds.). Tratado de Cariologia. Cultura Médica, Rio de Janeiro, 1988 , p.33-40.

30. Spets-Happonen, S.; Luoma, H.; Forss, H.; Kentala, J.; Alaluusua, S.; Luoma, A.R.; Gronross, L.; Syvaoja, S.; Tapaninen, H.; Happonen, P. Effects of a chlorhexidine-fluoride-strontium rinsing program on caries, gingivitis after rinsing with a chlorhexidine-fluoride solution with and without strontium. Scand. J. Dent. Res., 99: 329-335, 1991.

31. Zickert, I.; Emilson, C.G.; Ekblom, K.; Krasse, B. Prolonged oral reduction of Streptococcus mutans in humans after chlorhexidine disinfection followed by fluoride treatment. Scand. J. Dent. Res., 95:315-319, 1987. 